УДК 549.553

DOI: https://doi.org/10.17308/geology.2021.4/3790

Поступила в редакцию: 06.09.2021

Принята к публикации: 01.12.2021

Опубликована онлайн: 17.12.2021

\title{
Геологические условия образования цеолитовых месторождений Азербайджана
}

\author{
(C2021 В. М. Керимов ${ }^{\circledR}$ \\ Азербайджсанский Государственный Университет Нефти и \\ Промышленности, пр. Азадлыг, 34, АZ1101, Баку, Азербайджан
}

\begin{abstract}
Аннотация
Введение: Цеолиты являются наилучшими адсорбентами и поэтому привлекают пристальное внимание исследователей, а заодно находят широкое применение в различных отраслях промышленности и сельского хозяйства, причем с течением времени области их применения неизменно расширяются. Промышленная ценность цеолитов определяется, главным образом, наличием у них уникальных ионно-молекулярно-ситовых и каталитических свойств, обусловленных кристаллохимическими особенностями, их способностью к катионному обмену, потере и поглощению воды и других молекул без разрушения структурного каркаса. Особенно большое значение имеют природные цеолиты - клиноптилолит и морденит. Расширение отраслевой возможности использования цеолитов Азербайджана, где выгодно расположены крупные месторождения цеолитсодержащих туфов (Айдаг, Агдаг, Юхары Оксюзли, Татлы, Туг, месторождении в Талышской зоне и др.), настоятельно требует их комплексного изучения.

Методика: Для изучения состава цеолитов из различных месторождений проведены более 50 химических анализов цеолитизированных туфов, наиболее мелкие фракции клиноптилолитовых туфов подвергнуты минералогическому анализу. Определены показатели преломления микрочешуйчатого агрегата клиноптилолита и подсчитано количество минералов, дифракционные данные цеолитов получены при комнатной температуре на дифрактометре ДРОН-3 (CuKa - излучение, Niфильтр, 30 кВ, 20-26 мА, скорость движениясчетчика $0.500 /$ мин.).

Результаты и обсуждения: В статье анализируются состояние изученности и некоторые особенности природных цеолитов Азербайджана различного минерального и химического состава. По результатам химических анализов установлено, что состав минералов цеолитовой группы и цеолитизированных туфов Казахского прогиба характеризуется высоким содержанием кремнезема, преобладанием окисного железа над закисным, кальция над магнием и натрия над калием. Установлено, что собственно магматический цеолит представлен аналыцимом, который в виде ксеноморфных выделений расположен в интерстициях раннее выделившихся породообразующих минералов, таких как оливин, клинопироксен, плагиоклаз, биотит, роговая обманка и других в составе тешенитов Тугского и Калаханского интрузивов. Следующим генетическим типом цеолитов также является анальцим, который образовался в результате метасоматического преобразования высокотемпературного лейцита. Далее анализируются условия образования гидротермальных и осадочно-диагенетических цеолитов. Выяснено, что высококремнистые цеолиты, (клиноптилолиты и мордениты) имеюшие промышленное значение, образовались в результате гидратации кислых гиалокластитов дацит-риодацитового состава.
\end{abstract}

Контент доступен под лищензией Creative Commons Attribution 4.0 License.

\footnotetext{
Керимов Вагиф Мирзамехти, e-mail: vaqifkerimov1968@gmail.com
} 
Bblвoдbl: Установлено, что в большинстве случаев исходным материалом для образования цеолитов являются пепловые туфы трахиандезибазальтов, андезитов, дацитов и риодацитов. Разнообразие по составу продуктов эксплозивной деятельности позднемелового и кайнозойского вулканизма связано не только с условиями тектоно-магматического режима, хотя он и является одним из решающих факторов образования анальцимовых и клиноптилолит-морденитовых месторождений.

Ключевые слова: Природные цеолиты, условия образования, цеолитизированные туфы, Айдагское месторождение.

Для циитирования: Керимов В. М. Геологические условия образования цеолитовых месторождений Азербайджана // Вестник Воронежского государственного университета. Серия: Геология. 2021. №4. C. 53-62. DOI: https://doi.org/10.17308/geology.2021.4/3790

\section{Введение}

Цеолиты в Азербайджане как сырье, представляющее промышленный интерес, стали изучаться примерно четверть века назад, когда были выявлены их крупные месторождения. Исследования проводилась, с одной стороны - с точки зрения детального определения всевозможных свойств, а с другой - были поставлены геологоразведочные работы с целью оконтуривания их залежей и определения запасов. Природные цеолиты на территории Азербайджана изучены в достаточной мере и освещены в различных публикациях в республиканских и зарубежных изданиях. На основании собранных материалов и личных исследований сведения о природных цеолитах Азербайджана обобщены в монографии Мамедова М.Н., Махмудова С.А. и др. [1]. В данной работе рассмотрены геологические условия образования цеолитоносных комплексов, их классификация, минералогия, физико-химические условия образования и некоторые области использования природных цеолитов Азербайджана в различных отраслях сельского хозяйства и промышленности [1-3].

Среди природных цеолитов выделены магматические, гидротермальные и осадочно-диагенетические типы цеолитообразования [4]. Цеолиты Азербайджана в минералогическом аспекте разделены на одномерные, двумерные и трехмерные типы. Перечисленные генетические и различные структурно-минералогические типы цеолитов связаны преимущественно с позднемеловыми и кайнозойскими геологическими комплексами Азербайджанской части Кавказского сегмента альпийского пояса.

\section{Геологическая характеристика} цеолитовых месторождений Азербайджана

Цеолитоносные образования в основном широко распространены среди позднемеловых и кайнозойских комплексов в Казахском, Агджекендском, Агдеринском, Ходжавендском, Гочасском прогибах, в Вандамской и Талышской зонах, а также в Куринской межгорной впадине, Горном Талыше, Нахичеване, Кельбаджаре. Среди природных цеолитов наиболее ценными являются высококремнистые их разновидности, которые представлены Айдагским, Кемерлинским, Гаймахлинским, Юхары Оксюзлинским и Татлынским месторождениями [5].

В Талыш-Таромской структурно-формационной зоне анальцим развивается по пепловой цементирующей массе и составляет 40-70\% объема породы [6].

Помимо выше отмеченных месторождений клиноптилолитовые проявления обнаружены среди позднемеловых туфогенно-осадочных толщ Агдеринского прогиба (с. Суговушан). Здесь пепловые клиноптилолитовые туфы чередуются с белесовато-серыми туфами. Клиноптилолит ассоциируется с гейландитом, монтмориллонитом, анальцимом, кальцитом. Содержание клиноптилолита колеблется от 40 до $60 \%$.

Наиболее высоким содержанием анальцима (около 90\%) характеризуется Шуртанское проявление, расположенное на расстоянии около 2.5 км от селений Хархапут и Гюлистан Геранбойского района. Здесь анальцимизированные туфы (эоцен) согласно залегают среди плитчатых известняков кампанского и маастрихтского ярусов. Анальцимизированные мелкозернистые туфы обнаружены среди позднемеловых клиноптилолитовых туфов Агдеринского прогиба. Аутигенный или же осадочный анальцим обнаружен в средней части туфогенно-осадочной толщи позднего эоцена, развитой в Буроварском (Виляжчай, Улюмчай и др.) и Астаринском (Тангарючай, Астарачай и др.) поднятиях. Отдельные хорошо ограненные кристаллики анальцима отмечены в составе брекчии грязевого вулкана Гобу (близ Баку), состоящей из мелко- и среднезернистого песчаника [7].

Клиноптилолитовые проявления установлены в Горном Талыше, Араксчайской зоне, в Агдеринском и Кельбаджарском прогибах. В Горном Талыше [8] клиноптилолит в составе туфогенно-осадочной толщи среднего эоцена ассоциируется с гейландитом, кальцитом и анальцимом. В Араксчайской зоне установлен также в составе пепловых туфов среднего эоцена. Туфы характеризуются зеленовато-серой, синей окраской. Эти туфы в районе селений Кюки, Юхары Ремешин, Карабой в виде пласта небольшой мощности чередуются с белыми окварцованными пепловыми туфами. Протяженность цеолитоносной толщи достигает 15 км, мощность колеблется от 6 (на юго-востоке) до 10 м (на северо-восточной окраине с. Карабоя). Клиноптилолит присутствует в туфах в виде мелких кристаллов 0.10-0.01 мм. Он ассоциируется с кварцем, полевым шпатом и др.

Морденит-клиноптилолитовые туфы установлены в Кельбаджарском наложенном прогибе. Данное месторождение расположено около с. Аллолар. Площадь 
клиноптилолит-морденитовой минерализации состав-

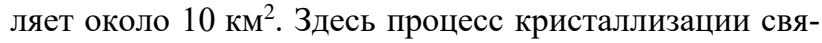
зан с изменениями эоценовых андезитов и их туфов.

В Агдажкендском прогибе, в отличие от Казахского развит дацит-риолитовый вулканизм коньякского и базальт-андезитобазальтовый сантонского времени. В строении данного прогиба принимают участие верхнеюрские, меловые и палеогеновые вулканогенные, вулканогенно-осадочные и осадочные образования. Здесь цеолитовая минерализация имеет гидротермальный генетический тип и преимущественно заполняет трещины, миндалины, пустоты и т.д. По породообразующим минералам особенно по плагиоклазу, цеолитизация встречается редко.

В Азербайджанской части Лок-Карабахской структурно-формационной зоны в отношении клиноптилолитовых и клиноптилолит-морденитовых месторождений наиболее перспективным является Казахский прогиб, который расположен в полосе погружения мегантиклинория Малого Кавказа под четвертичные молассы Средне-Куринской впадины. Прогиб выполнен преимущественно верхнеюрскими эффузивными, осадочно-пирокластическими и нормально-осадочными комплексами. Все цеолитизированные пачки согласно залегают в одном и том же стратиграфическом горизонте, т.е. находятся среди отложений позднего сантона и раннего кампана [9].

В целом, для Казахского прогиба может быть выделено три перспективных участка: северо-западный, центральный и восточной. На северо-западном участке клиноптилолитовые пласты, протяженностью 20 25 км, прослеживаются от села Алибайрамлы и продолжаются на территории соседней республики. Здесь морденит заметно преобладает над клиноптилолитом. При этом содержание кремнезема в составе туфов заметно высокое. На восточном участке Казахского прогиба, куда входит, собственно, Айдагское месторождение, клиноптилолит преобладает над морденитом. Здесь трассы, имеющие сравнительно крупнозернистую гранулометрию, менее цеолитизированы и являются продуктом ранней стадии эксплозии позднесантонского вулканизма [10-12].

В краевых частях Казахского прогиба развиты Айдаг, Татлы, Кероглы, Агдаг, Кярамли и Гаймахлынское клиноптилолитовые и клиноптилолит-морденитовые месторождения. Среди перечисленных месторождений наиболее крупным и хорошо изученным является Айдагское месторождение, которое было выбрано в качестве основного объекта исследований. Месторождение размещается в моноклинали Кероглинской синклинальной структуры второго порядка и приурочено к зоне пересечения антикавказского разрыва с общекавказским разломом. В узлах пересечения структур обоих направлений возникла сеть тектонических трещин, обусловивших развитие гидротермального метасоматоза и, в частности, цеолитизации пепловых гиалокластитов [11].

Пепловые туфы массивные, тонкозернистые залегают среди карбонатных отложений верхнего сантон- кампанского яруса в виде пластовой залежи мощностью в среднем 25-30 м. Ширина выхода на дневную поверхность туфов составляет 20-120 м при общем протяжении до 3 км. Разрывные нарушения делят месторождение на 3 участка: западный, центральный и восточный. Наиболее перспективным является центральный участок, где протяженность выхода на поверхности составляет 200 м. Установлено наличие трех пластов: 1) светло-серые туфы; 2) буровато-серые туфы; 3) нижний - голубовато-серые трассы (рис. 1, 2).

\section{Методика исследований}

В основу данной статьи положен анализ материалов полевых и лабораторных исследований автора, изучающего позднемеловой вулканизм Казахского прогиба и связанные с ним месторождения высококремнистых цеолитов. Для решения поставленных задач проведено около 50 химических анализов цеолитизированных туфов, а также использованы результаты геологических, геохимических, петрологических исследований в этом районе с привлечением фондовых и опубликованных материалов, по собственным полевым наблюдениям составлены схематические геологические карты Айдагского месторождения.

По данным гранулометрических анализов, выполненных Н. Ф. Челищевым и др. [13], наиболее мелкие фракции клиноптилолитовых туфов подвергнуты минералогическому анализу. Определены показатели преломления микрочешуйчатого агрегата клиноптилолита $(\mathrm{N}=1.480)$ и подсчитано количество минералов: клиноптилолит - 76-80\%, кварц $-14-16 \%$, кальцит $2-2.5 \%$.

По результатам химических анализов установлено, что состав минералов цеолитовой группы и цеолитизированных туфов Казахского прогиба характеризуются высоким содержанием кремнезема, преобладанием окисного железа над закисным, кальция над магнием и натрия над калием.

Дифракционные данные цеолитов получены при комнатной температуре на дифрактометре ДРОН-3 (CuK $\alpha$ - излучение, Ni-фильтр, 30 кB, 20-26 мА, скорость движения счетчика 0.50 Ө/мин.). Каждый образец изучался по 3 раза. В качестве внутреннего эталона использовали положение линии $\mathrm{KBrO}_{3}$ $(2 \theta=20.2120)$ и кварц $(2 \theta=40.2980 ; 50.1460)$. Точность определения $\pm 1 \%$.

\section{Обсуждение результатов}

Позднемагматический цеолит представлен породообразующим анальцимом. Он в виде ксеноморфных выделений располагается в интерстициях ранее выделившихся плагиоклазов, клинопироксенов, биотитов, роговой обманки в составе Тугских и Калаханских тешенитов. По данным рентгеноструктурного ( $\mathrm{a}=13.72$ Á) и химического анализов (табл. $1 .$, ан.1, 2) его состав близок к теоритическому.

В гидротермальных анальцимах выявлена ощутимая концентрация рубидия (100-200 г/т), бария (200-259 г/т) и оксида калия (1.5-2.5\%). По всей вероятности, данный 
анальцим является продуктом преобразования первичного лейцита. Нередко содержание упомянутого минерала в составе вышеотмеченных пород достигает 40$60 \%$. Учитывая повышенное содержание глинозема
$\left(\mathrm{Al}_{2} \mathrm{O}_{3}-23.69 \%\right)$ и натрия $\left(\mathrm{Na}_{2} \mathrm{O}-12.78 \%\right)$ в составе этих анальцимов и достаточную площадь их распространения, этот тип может представлять собой промышленной интерес [11].

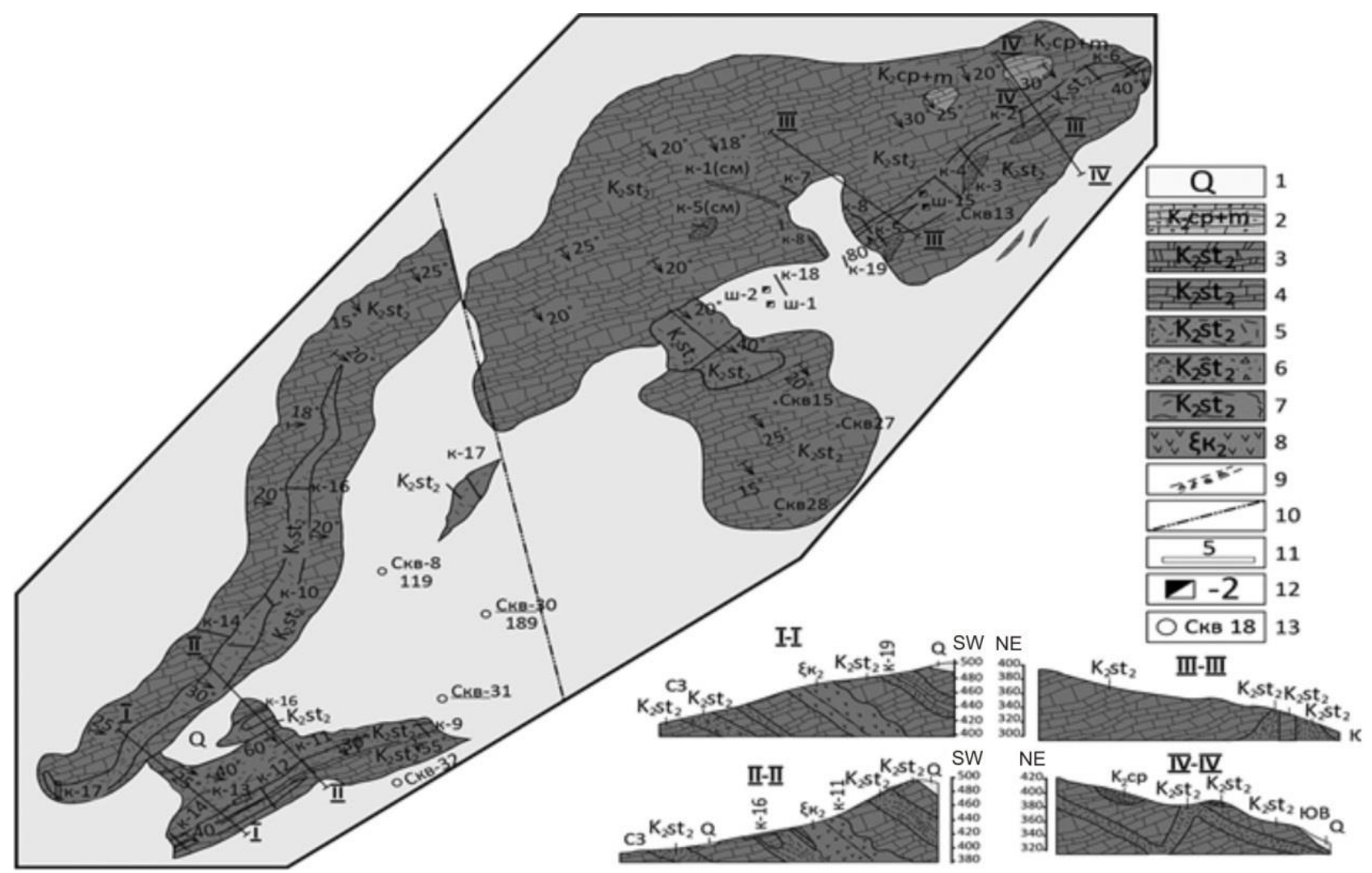

Рис. 1. Схематическая геологическая карта Айдагского месторождения: 1 - четвертичные отложения: суглинки, супеси; 2 -кампан-маастрихский ярус: известняки беловато-сероватого цвета, крупнозернистые, песчанистые; 3-7 - верхнесантонский подъярус: 3 красноцветные слабопесчанистые известняки; 4 - известняки мергелеподобные, пелитоморфные, сильно трещиноватые; 5 - цеолитосодержащие туфы, голубовато-серые; 6 - цеолитосодержащие туфы, сильно окремненные и брекчированные; 7 - цеолитосодержащие «трассы», голубоватые; 8 - верхний мел: диоритовые порфириты; 9 - гидротермально-измененные породы; 10 - разрывные нарушения; 11- канавы и их номера; 12 - шурфы и их номера; 13 - скважины и их номера (Масштаб 1:2000).

[Fig. 1. Schematic geological map of the Aydag deposit: (1) - Quaternary deposits: loam, sandy loam; (2) - Campanian-Maastrichian stage: limestones of whitish-grayish colour, coarse-grained, sandy; (3-7) Upper Santonian substage: (3) - red-coloured weakly sandy limestones; (4) - marl-like limestones, pelitomorphic, highly fractured; (5) - zeolite-bearing tuffs, bluish-gray; (6) - zeolite-bearing tuffs, highly silicified and brecciated; (7) - zeolite-bearing blue "trasses"; (8) - Upper Cretaceous: diorite porphyrites; (9) - hydrothermally altered rocks; (10) - breaking disturbances; (11) - ditches and their numbers; (12) - pits and their numbers; (13) - wells and their numbers (Scale 1:2000).]
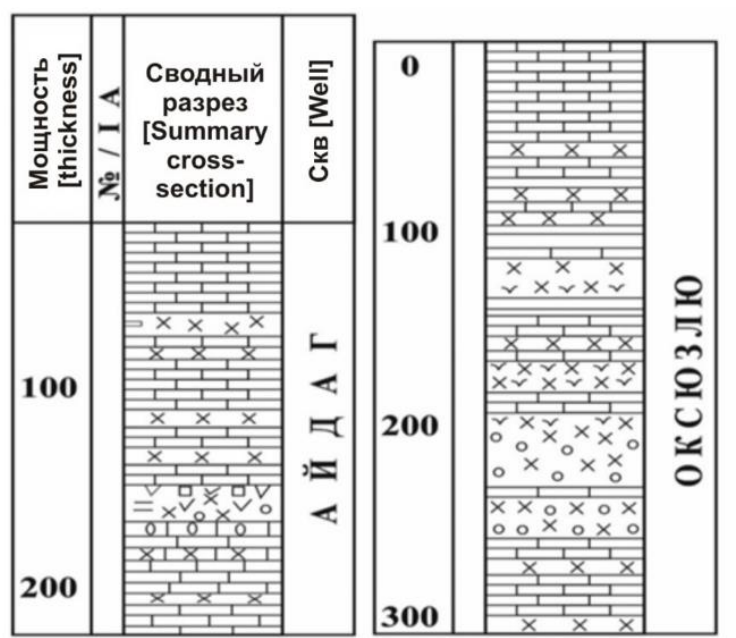

Рис. 2. Сводный литологический разрез Айдагского и Оксюзлюнского месторождений: 1 пеплы, пепловые туфы (клиноптилолитовые); 2 пеплы мергелеподобные (кремнисто-анальцимовые); 3 - брекчиевые литокластические и кристалловитрокластические туфы; 4 - линзы и включения бентонитов; 5 - известняки органогенные пелитоморфные.

[Fig. 2. Composite lithological section of the Aydag and Oksyuzli deposits: (1) - ashes, ash tuffs (clinoptilolite); (2) - ashes, marl-like (siliceous-analcime); (3)

4 - breccia lithoclastic and crystalline-vitroclastic tuffs; (4) - lenses and bentonite inclusions; (5) - organogenic pelitomorphic limestones. Inscriptions on the picture: Aйдаг - Aydag, Оксюзлю - Oksyuzlu.] 
Макроскопически клиноптилолитовый туф характеризуется светлой, светло-серой и зеленовато-серой окраской. Клиноптилолитовые туфы имеют мелкозернистое и плотное строение. Под микроскопом наблюдается криптозернистое, игольчатое, чешуйчатое строение туфа клиноптилолита. Помимо последнего, как цементирующая масса, отмечаются бесформенные выделения кальцита, доломита. Наряду с ними нередко в составе участвуют в различной степени девитрифицированные остатки буровато-серого стекла дацитового и риодацитового состава.

Помимо этого, в шлифах обнаружены угловатые обломки кварца (0.02-0.4 мм), таблички полевых шпатов (0.04 мм) и биотита (0.015-0.1 мм). Мелкие чешуйки хлорита иногда образуют обособленные скопления. В незначительных количествах встречаются гидроокись железа и скопления криптокристаллических карбонатов, образующих с цеолитами тонкие прорастания. По гранулометрическому составу клиноптилолитовые туфы представлены следующими фракциами: > 0.25 мм - 4.7-18.6\%; 0.25-0.1 мм - 5-12.1\%; < $0.1-0,01$ мм - 46.8-64.2\%; <0.01 мм-21.2-31.9\% (табл. 1 , анализы 1,2$)$. Результаты анализов показывают, что количество цеолитов в легкой фракции размерностью 0.1-0,01 мм колеблется от 75 до 95\%, остальная часть фракции представлена алюмосиликатами, частично измененными полевыми шпатами и карбонатами. В тяжелой фракции проб преобладают биотит и хлорит. В качестве акцессорных минералов обнаружены роговая обманка, целестин, циркон, ильменит, магнетит и единичные зерна турмалина, сфена, авгита, граната и пирита.

По данным М. Н. Мамедова и др. [4] клиноптилолит в Айдагском месторождении находится в ассоциации с морденитом, гейландитом, натролитом, стильбитом, анальцимом и другими минералами в виде игольчатых и волокнистых скоплений. Чаще всего он бесцветен. Скопления мелких (0.01-0.03 мм) кристаллов клиноптилолита образуют псевдоморфозы преимущественно по полевым шпатам. В цементирующей массе клиноптилолит развивается по полевому шпату и кварцу. В большинстве случаев наблюдаются реликты вулканического стекла. Для клиноптилолита из Айдагского месторождения определены показатели преломления $\mathrm{Ng}$ $=1.480-1.483 ; \mathrm{Np}=1.478-1.481$. Ассоциирующий с ним гейландит характеризуется более высокими показателямипреломления: $\mathrm{Ng}=1.501 ; \mathrm{Np}=1.497$.

Изучение химического состава клиноптилолитовых и клиноптилолит-морденитовых туфов (табл. 1, ан. 3-8) показало высокое содержание кремнезема, преобладание окисного железа над закисным, кальция над магнием, натрия над калием. В целом, химический состав гиалокластитовых туфов, слагающих отдельные разрезы верхнего сантона и нижнего кампана, меняется с северо-западанавостоквсторонуувеличениящелочности, железистости и уменьшения известковистости.

В результате изучения химического состава (см. табл. 1, ан. 3) установлено, что Айдагский клиноптилолит относится к натриево-кальциевой разности с пониженным содержанием калия. Однако эти изменения не влияют на общую характеристику туфов и позволяют предположить их принадлежность кединой первичной магме дацитового и риодацитового состава.

В составе цеолитизированных туфов и «трассов» Казахского прогиба по результатам спектральныханализов установлены (г/т): стронций 210 , барий 200 , титан 400 , церий 80, цинк 200, свинец 200. Перечисленные элементы могут как изоморфно входить в состав кристаллокластов, так и быть рассеянными в цементирующей массе (табл. 1).

Табл. 1. Химический состав клиноптилолитовых туфов Казахского прогиба, \%, [4].

[Table. 1. Chemical composition of clinoptilolite tuffs of the Kazakh trough, \%, [4]].

\begin{tabular}{|c|c|c|c|c|c|c|c|c|c|c|}
\hline \multirow{2}{*}{$\begin{array}{c}\text { Состав } \\
\text { [Composition] }\end{array}$} & \multicolumn{2}{|c|}{$\begin{array}{c}\text { Анальцим } \\
\text { [Analcime] }\end{array}$} & \multicolumn{9}{|c|}{ Клиноптилолитовые туфы } \\
\cline { 2 - 13 } & 1 & 2 & 3 & 4 & 5 & 6 & 7 & 8 & 9 & 10 \\
\hline $\mathrm{SiO}_{2}$ & 54.23 & 52.47 & 65.95 & 64.66 & 67.50 & 68.25 & 69.74 & 67.8 & 63.0 & 67.7 \\
\hline $\mathrm{Al}_{2} \mathrm{O}_{3}$ & 24.16 & 24.62 & 12.13 & 11.17 & 10.63 & 10.50 & 11.13 & 11.1 & 9.97 & 10.5 \\
\hline $\mathrm{Fe}_{2} \mathrm{O}_{3}$ & - & 0.41 & 1.22 & 1.26 & 0.30 & 0.11 & 0.24 & 0.24 & 0.40 & 0.36 \\
\hline $\mathrm{FeO}$ & 0.06 & - & 0.07 & 0.05 & 0.07 & 0.05 & - & - & - & - \\
\hline $\mathrm{MnO}$ & - & - & 0.02 & 0.01 & 0.02 & 0.02 & 0.02 & 0.02 & 0.02 & 0.02 \\
\hline $\mathrm{MgO}$ & - & 0.32 & 0.99 & 1.09 & 0.32 & 0.75 & 0.87 & 0.54 & 1.12 & 0.65 \\
\hline $\mathrm{CaO}$ & 0.63 & 1.40 & 3.63 & 3.70 & 8.15 & 6.68 & 5.68 & 6.91 & 9.82 & 7.29 \\
\hline $\mathrm{Na}{ }_{2} \mathrm{O}$ & 12.74 & 11.16 & 1.37 & 2.23 & 2.12 & 2.10 & 2.12 & 1.69 & 1.42 & 1.51 \\
\hline $\mathrm{K}_{2} \mathrm{O}$ & 0.34 & 1.47 & 1.95 & 2.15 & 1.70 & 2.10 & 2.12 & 1.69 & 1.68 & 2.10 \\
\hline $\mathrm{H}_{2} \mathrm{O}+110$ & 7.94 & 8.05 & 8.26 & 8.74 & 7.06 & 8.56 & 8.08 & 9.24 & 12.1 & 9.05 \\
\hline $\mathrm{H}_{2} \mathrm{O}-110$ & 0.20 & - & 3.38 & 4.26 & 2.92 & 1.04 & 1.98 & - & - & - \\
\hline$\Sigma$ & 100.30 & 99.90 & 98.97 & 99.37 & 100.72 & 100.01 & 99.98 & 99.3 & 99.6 & 99.2 \\
\hline
\end{tabular}


Клиноптилолит представляет собой прозрачные кристаллы размером 0.03-0.5 мм, псевдоромбического облика, с совершенной спайностью по (010) и ярким алмазным блеском. На порошковых дифрактограммах клиноптилолит характеризуется диффракционными эффектами, с межплоскостными расстояниями (9.09.1, , 3.96-3.97 $\AA, 2.97-2.98 \AA$ и ряд более слабых). На дифрактограммах интенсивные рефлексы $d=8.9-8.98$; $3.95 ; 3.4$ и 2.96-2.97 $\AA$, а также ряд других слабых отражений $\mathrm{d}=7.8-7.91 ; 6.66-6.68 ; 5.2-5.28 ; 5.09-5.1 ; 4.63-$ $4.65 ; 3.16-3.21$ и 2.78-2.79 А позволяют диагностировать основную массу как клиноптилолит (рис. 3).
В отличие от клиноптилолита природный морденит четко определяется рентгенометрическим анализом. Под микроскопом строение морденита представлено спутанно-волокнистыми или радиально-лучистыми агрегатами тончайших игловидных кристаллов с низким двупреломлением. Погасание прямое, удлинение отрицательное. Морденит образуется по вулканическому стеклу, замещая как обломки стекла, так и стекло цементирующей основной массы. На дифрактограммах интенсивные рефлексы $d=9.04-9.16 ; 6.59-6.63 ; 4.49$; $3.98 ; 3.47 ; 3.35 ; 3.20-3.22 \AA$ позволяют диагностировать морденит (рис. 4).

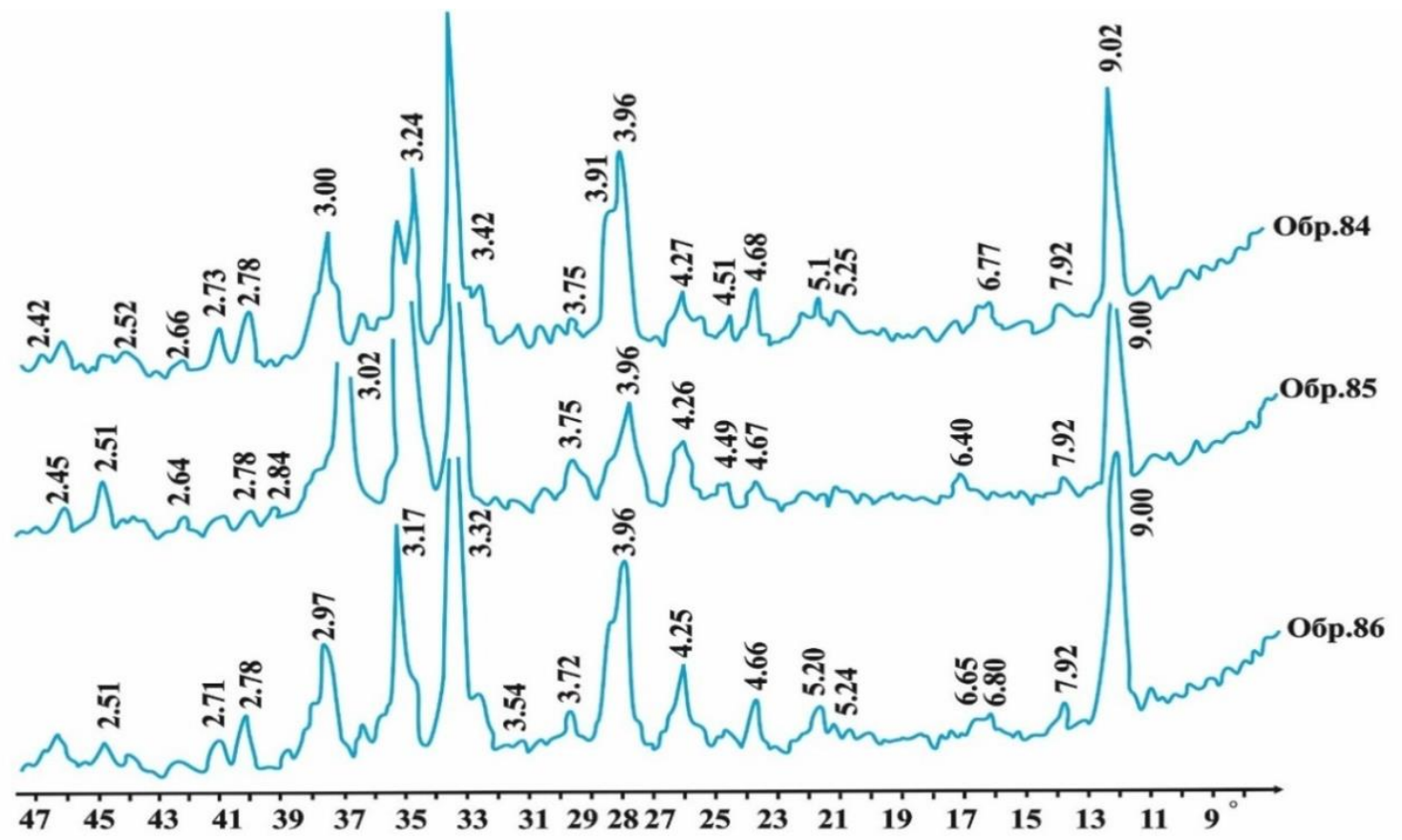

Рис. 3. Дифрактограмма цеолитизированных «трассов» месторождения Айдаг.

[Fig. 3. Diffraction pattern of zeolitised "trasses" of the Aydag deposit.]

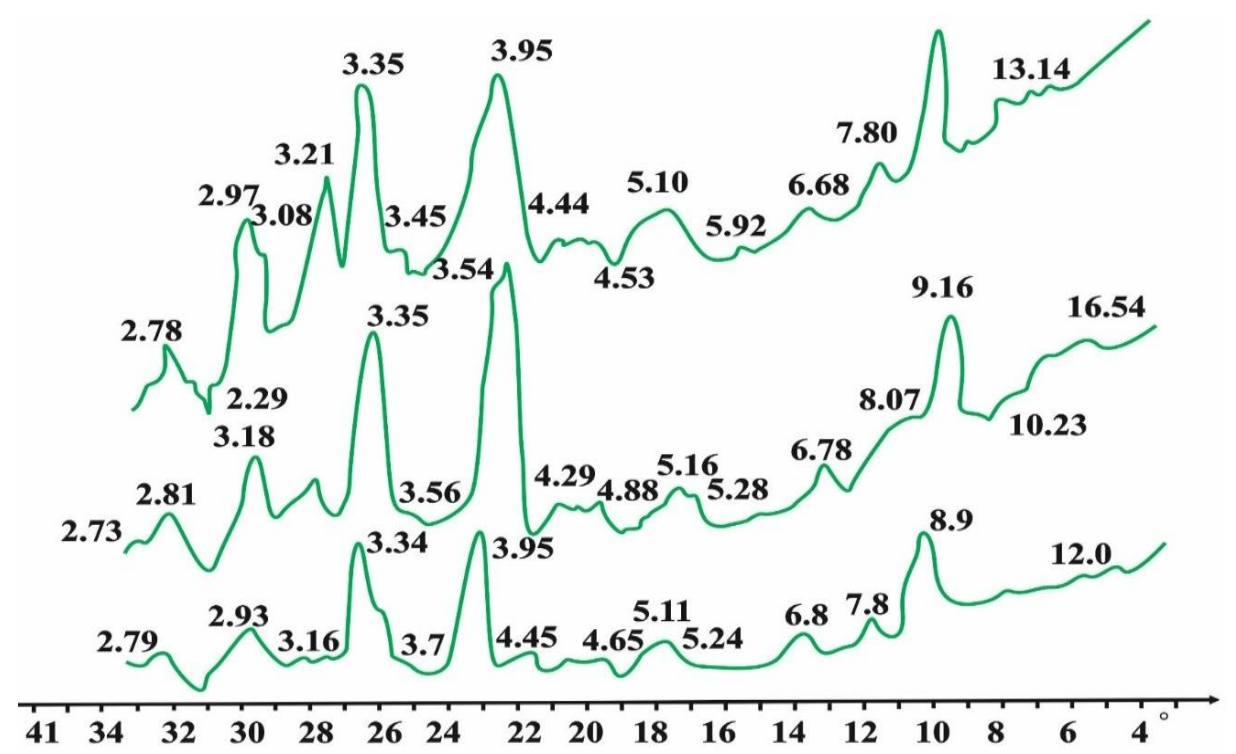

Рис. 4. Дифрактограммы морденита с клиноптилолитом в витрокластических туфах.

[Fig. 4. Diffraction patterns of mordenite with clinoptilolite in vitroclastic tuffs.] 
В отличие от клиноптилолитовых пород, в которых наряду с кварцем нередко присутствуют кристобалит, в морденитовых породах устанавливается только кварц. Морденитовые породы под микроскопом неотличимы от клиноптилолитовых.

Гидротермальные цеолиты в отличие от магматического анальцима характеризуются большим разнообразием минерального состава и широким распространением. Они приурочены к миндалинам, пустотам, трещинам и другим образованиям вулканогенных пород. Эти цеолиты представлены анальцимом, натролитом, мезолитом, сколецитом, ломонтит-леонгардитом, стильбитом, этистильбитом, шабазитом, гейландитом, клиноптилолитом, морденитом, томсонитом, вайракитом.

Гидротермальный анальцим, представляющий интерес, образует нечетко ограненные кристаллы молочно-белой и сероватой окраски. Сравнительно крупные хорошо ограненные кристаллы тетрагон-триоктаэдрического габитуса, размером 2.5 см, встречены в составе лейцитового фонолита и мегаплагиопорфирового латита Талыш-Таромской зоны (села Пештасар, Рази) $[14,15]$. В этих кристаллах обнаружены концентрически расположенные хлоритизированные микровключения, иголки эгирина и др. Вместе с тем, сравнительно мелкие, но хорошо ограненные выделения их установлены в составе абсарокитов Госмальянского прогиба этой зоны. В анальцимах выявлена ощутимая концентрации рубидия (100-200 г/т), бария (200-250 г/т) и оксида калия (1.5-2.5\%). Данный анальцим, очевидно, является продуктом преобразования первичного лейцита. Нередко содержание упомянутого минерала в отмеченных породах достигает 40-60\%.

Осадочно-диагенетический анальцим развит в Талыш-Таромской структурно-формационной зоне. Здесь анальцимизированные туфы трахиандезибазальтов приурочены к юго-западному борту Астаринского поднятия и прослеживаются от Госмальянского прогиба в юго-восточном направлении и через Шандан галасы переходят на территорию Ирана (ранний эоцен). Тонко-мелкозернистые анальцимизированные туфы мощностью от 5 до 20 м перекрывают размытую поверхность дат-палеоценового туфогенно-осадочного комплекса. Верхний же горизонт представлен среднекрупнозернистыми анальцим-санидиновыми туфами трахиандезибазальтов (трахитов). Здесь по мере увеличения снизу вверх размерности обломков пород и минералов, процесс анальцимизации уменьшается. Наряду с анальцимом в туфах в подчиненном количестве отмечаются гейландит и ломонтит.

Ломонтит-леонгардитовые проявления установлены в составе цементирующего материала базального конгломерата, приуроченного к основанию флишоидной толщи среднего эоцена Талыша. Гейландитовая цеолитизация в виде маломощных (0.2-10 см) прослоев располагается в нижней части среднеэоценовой туфогенно-осадочной толщи. Гейландитовая прослойка имеет мясо-серую окраску и средне-мелкозернистую гранулометрию. Гейландит развивается по пепловой цементирующей массе отмеченных туфопесчаников.

Анализ распространения перечисленных месторождений осадочно-диагенетического цеолитообразования показал, что в большинстве случаев исходным материалом для образования цеолитов являются пепловые туфы трахиандезитобазальтов, андезитов, дацитов и риодацитов. Разнообразие по составу продуктов эксплозивной деятельности позднемелового и кайнозойского вулканизма связано не только с условиями тектоно-магматического режима, хотя он является одним из решающих факторов образования анальцимовых и клиноптилолит-морденитовых месторождений. Несомненно, исходным материалом для образования анальцимовых и клиноптилолит-морденитовых туфов явились трахиандезитобазальтовые, андезитодацитовые, дацитовые и риодацитовые пепловые частицы гиалокластитов позднего мела (верхний сантон, нижний кампан) и кайнозоя (палеоцен, эоцен). Извержения отмеченных гиалокластитов происходили в субмаринных и субареальных условиях [16-19].

Как известно, в позднемеловое время (верхний сантон) в пределах Кавказского сегмента Средиземноморского пояса, благодаря продолжающимся субдукционным процессам, происходит уменьшение проницаемости продольных магмаподводящих разломов, усиливается активность поперечных разломов [20-21]. В этой связи, подъем среднего, среднекислого, кислого по составу вязкого расплава на земную поверхность затрудняется и происходит закупорка вулканического жерла. По мере обогащения нижних частей магмаподводящего канала летучими компонентами создаются высокобарические условия. Изменение соотношения давления способствует раздроблению и выбросу средних и среднекислых гиалокластитов. При этом верхняя часть материала закупоренных вулканических центров подвергается раздроблению в меньшей степени, поэтому ранний продукт выброса соответствует грубозернистым, в дальнейшем цеолитизированным туфам. Продукты же средней и нижней части закупоренных каналов испытывают большее раздробление. Последние в виде мелких пепловых гиалокластитов выбрасываются и осаждаются в шельфовой зоне близ расположенного моря. Здесь, благодаря взаимодействию горячих пепловых гиалокластитов с холодной морской водой в условиях щелочной среды, происходит девитрификация этих стекол с образованием анальцимовой, клиноптилолит-морденит-гейландитовой цеолитизации.

\section{Выводы}

1. Формирование месторождений цеолитов определяется, в основном, составом исходного материала, фациальными условиями его отложения и характером катагенетических преобразований вмещающих их пород. Исходным материалом для образования цеолитов, как правило, служит вулканическое стекло кислого, среднего, редко основного состава, содержащееся в туфах.

2. Локальное (или ареальное) распространение анальцимовых, гейландитовых, клиноптилолитовых и 
морденитовых туфов вокруг вулканических центров указывает, что эксплозивную деятельность вулканов характеризуется центральным типом извержения, т.е. они расположены в зоне пересечения продольных и поперечных разломов.

3. Анальцимовые, гейландитовые, клиноптилолитовые и морденитовые туфы, образующие проявления и крупные месторождения, являются продуктом преобразования пепловых трахиандезибазальтовых, андезито-дацитовых, дацитовых и риодацитовых гиалокластитов в щелочной морской среде.

4. Частое нахождение морденита и клиноптилолита в одних и тех же породах доказывает, что условия их образования перекрываются, но тем не менее морденитовые породы в отличие от клиноптилолитовых часто тяготеют к контактам субвулканических тел риолитов и разрывным нарушениям, залегают среди плотных известняков и вблизи лавовых потоков и грубых туфов.

5. Рекомендуется возобновить разработку Айдагского и других месторождений цеолитов и использование их в медицине для лечения различных заболеваний, а также для очистки загрязненных питьевых вод, осушки и очистки веществ (радионуклидов), добавки при производстве цемента, компонентов удобрительных смесей и т.д.

Конфликт интересов: Авторы декларируют отсутствие явных и потенциальных конфликтов интересов, связанных с публикацией настоящей статьи.

\section{ЛИТЕРАТУРА}

1. Мамедов М. Н., Махмудов С. А., Панахи К. А., Абдуллаева Н. М. Минералы цеолитовой группы Азербайджана. Баку: Изд. Нафта-Пресс. 2000. 161 с.

2. Тагиев И. И. Природные цеолиты Азербайджана. Материальы Международного Симпозиума. Баку. 1999. С. 27-33.

3. Кашкай М. А., Бабаев И. А. Клиноптилолит, его физические свойства и генезис. Сб.: Минералы и парагенезисы минералов горных пород. Изд. Наука. Л. 1976. С. 76-90.

4. Мамедов М. Н., Керимов В. М., Абдуллаева Н. М. Некоторые минералогические особенности распространения природных цеолитов // Физика, математика, науки о Земле. 2005. № 1 (21). C. 38-44.

5. Мамедов М. Н. Петрология и геохимия позднемеловых и эоценовых магматических формаций Малого Кавказа и Талыша. Баку, Nafta-Press, 1999. 400 c.

6. Азизбеков Ш. А., Мамедов М. Н. Цеолиты субщелочной базальтоидной формации Талыша // Изв. АН ACCP. сер. Науки о Земле. № 3. 1974. С. 83-95.
7. Белянкин Д. С., Самойлова Н. В., Петров В. П. Анальцим и лейцит в вулканическом эоцена Талыша. Тр. Минер. Муз. М. Издательство Академии наук СССР, Москва. В. 3. 1951. C. $3-9$.

8. Амиров С. Т., Мамедов М. Н., Мамедов Х. С. Цеолиты Азербайджана (Горный Талыш). Сб.: Исслед. В обл. неорг. и физик. химии. Баку: Изд. Элм, 1977. С. 190-202.

9. Абдуллаев Р. Н., Ализаде Х. А., Хеиров М. Б. Бентонитообразование и цеолитовая минерализация в меловых отложениях Малого Кавказа (Казахский прогиб). Петролого-минералогические особенности пород и технических камней. М.: Наука, 1979. С. $170-180$.

10. Расулова С. К. О некоторых закономерностях цеолитовой минерализации в позднемеловых вулканогенно-осадочных комплексах Казахского прогиба (Малый Кавказ) // Вестник Бакинского Университета, серия естественных наук. 2015. № 2. C. 92-99.

11. Расулова С. К., Баба-заде В. М. Белоусов П. Е., Мамедов М. Н., Имамвердиев Н. А., Керимов В. М., Викентьев И. В. Условия образования цеолитовых месторождений Казахского прогиба Малого Кавказа // Вестник РУДН. Серия: Инженерные исследования. 2017. Т. 18. № 4. С. 480-496.

12. Кулиев А. И., Гамзаев О. Д. Цеолиты.Геология СССР. Т.47. Полезные ископаемые. М.: Недра. 1976. 105 с.

13. Челищев Н. Ф., Беренштейн Б. Г., Володин В. Ф. Цеолиты новый тип минерального сырья. М.: Недра. 1987. 176 с.

14. Азизбеков Ш. А., Багиров А. Э., Велиев М. М., Исмаилзаде А. Д., Нижерадзе Н. Ш., Емельянова Е. Н., Мамедов М. Н. Геология и вулканизм Талыша. Баку: Издат. Элм. 1979. $246 \mathrm{c}$.

15. Керимов В. М. Петрология и минеральный парагенезис трахибазальт-трахиандезит-фонолитовой формации Талышской зоны: автореф. дис ... канд. геол.-мин. наук. Баку, 2007. $22 \mathrm{c}$.

16. Исмаил-заде А. Д., Мустафаев Ф. А. О цеолитах Талыша // Изв. АН Азерб. ССР. сер. геол.-геогр. наук. Баку: 1964. № 5. C. $65-70$.

17. Мамедов М. Н., Бабаева Г. Д., Керимов В. М. Клинопироксены в процессе формирования субщелочной оливинбазальтовой магмы Талышской зоны Кавказа // Уральский Геологический Журнал. 2017. № 5 (119). С. 39-54.

18. Керимов В. М. Геологические условия формирования трахибазальт-трахиандезибазальт-фонолитовой формации Талышской зоны (Азербайджан) // Екоенергетика НТЖ. 2016. № 4. C. 50-55.

19. Керимов В. М. Условия генерации субщелочных и щелочных базальтоидных серий Талыша // Уральский геологический журнал. 2020. № 3 (135). С. 35-43.

20. Михайлов А. С. Месторождения высококремнистых цеолитов Закавказья // Советская геология. 1975. № 9. С. 70-78. 21. Чхеидзе Р. Г. Месторождения высококремнистых цеолитов Закавказья и геологические предпосылки их освоения: автореф. дисс. ... канд. геол.-мин. наук. Тбилиси, 1981. 25 с. 
UDC 549.553

ISSN 1609-0691

DOI: https://doi.org/10.17308/geology.2021.4/3790

Received: 06.09.2021

Accepted: 01.12.2021

Published online: 17.12.2021

\title{
Geological conditions for the formation of zeolite deposits in Azerbaijan
}

\author{
(C)2021 V. M. Karimov ${ }^{凶}$
}

\author{
Azerbaijan State University of Oil and Industry, 34 Azadlıq pr., Baku AZ-1010, Azerbaijan
}

\begin{abstract}
Introduction: Zeolites are the best adsorbents, and for this reason they attract close researcher's attention. At the same time, they are widely used in various industrial sectors and agriculture, and over time the areas of their application constantly expand. The industrial value of zeolites is mainly determined by their unique ion-molecular sieve, and catalytical properties associated with the crystallochemical peculiarities of zeolites, their ability for cation exchange as well as loss and absorption of water and other molecules without the destruction of the structural framework. Natural zeolites, such as clinoptilolite and mordenite, are especially significant. Their comprehensive study is required due to the expansion of the industrial opportunities to utilize the zeolites of Azerbaijan, where large deposits of zeolite-containing tuffs are favourably situated (Aydag, Agdag, Yukhary Oksyuzli, Tatly, Tug, Talysh deposits, etc.).

Methodology: To study the composition of zeolites from various deposits, were conducted more than 50 chemical analyses of zeolitised tuffs and performed the mineralogical analysis of the smallest fractions of clinoptilolite tuffs. The refraction index of the micro-flaked aggregate of clinoptilolite was determined and the amount of minerals was calculated, the diffraction data of zeolites were obtained at room temperature on a DRON-3 diffractometer (CuK $\alpha$ radiation, Ni filter, $30 \mathrm{kV}, 20-26 \mathrm{~mA}$, counter speed 0.50 $\theta / \mathrm{min}$.).

Results and discussions: The article analyses the current state of study and some peculiarities of natural zeolites of Azerbaijan with various mineral and chemical compositions. According to the results of chemical analyses, we found that the composition of the minerals from the zeolite group and zeolitised tuffs of the Kazakh trough is characterised by a high content of silica, the predominance of iron oxide over ferrous iron as well as the predominance of calcium over magnesium and sodium over potassium. It was established that the magmatic zeolite is represented by analcime which is located in the form of xenomorphic segregations in the interstice of early rock-forming minerals, such as olivine, clinopyroxene, plagioclase, biotite, hornblende, and others, as part of the teschenites of the Tugh and Kalakhan intrusions. The next genetic type of zeolites is analcime that was formed as a result of the metasomatic transformation of high-temperature leucite. Further, the conditions for the formation of hydrothermal and sedimentary-diagenetic zeolites were studied. It was found that high-silica zeolites (clinoptilolites and mordenites), which are of industrial value, had been formed as a result of hydration of acidic hyaloclastites with a thedacite-rhyodacite composition. Conclusions. It was established that in most cases ash tuffs of trachyandesibasalts, andesites, dacites, and rhyodacites are the initial material for the formation of zeolites. The diversity in the compositions of the products of the explosive activity of Late Cretaceous and Cenozoic volcanism is associated not only with the conditions of the tectonic and magmatic mode, although it is one of the critical factors in the formation of analcime and clinoptilolite-mordenite deposits.
\end{abstract}

Keywords: natural zeolites, conditions of formation, zeolitised tuffs, Aydag deposit.

For citation: Karimov V. M. Geological conditions for the formation of zeolite deposits in Azerbaijan. Vestnik Voronezhskogo gosudarstvennogo universiteta. Seriya: Geologiya - Proceedings of Voronezh State University. Series: Geology, 2021, no. 4, pp. 53-62. DOI: https://doi.org/10.17308/geology.2021.4/3790

\footnotetext{
$\bowtie$ Vagif M. Karimov, e-mail: vaqifkerimov1968@gmail.com
} 
Conflict of interests: The authors declare the absence of obvious and potential conflicts of interest related to the publication of this article.

\section{REFERENCES}

1. Mamedov M. N., Makhmudov S. A., Panakhi K. A., Abdullaeva N. M. Mineraly ceolitovoj gruppy Azerbajdzhana [Minerals of the zeolite group of Azerbaijan]. Baku, Nafta-Press publ., 2000. 161 p. (İn Russ.).

2. Tagiev I. I. Prirodnye ceolity Azerbajdzhana [Natural zeolites of Azerbaijan]. Materials of the International Symposium. Baku, 1999, pp. 27-33. (In Russ.).

3. Kashkai M. A., Babaev I. A. Klinoptilolit, ego fizicheskie svojstva i genezis [Clinoptilolite, its physical properties and genesis]. Mineraly i paragenezisy mineralov gornykh porod [Minerals and paragenesis of rock minerals]. Leningrad, Nauka publ., 1976, pp. 7690. (İn Russ.).

4. Mamedov M. N., Kerimov V. M., Abdullaeva N. M. Nekotorye mineralogicheskie osobennosti rasprostraneniya prirodnyh ceolitov [Some mineralogical features of the distribution of natural zeolites] Fizika, matematika, nauki o Zemle - Physics, mathematics, earth sciences, 2005, no. 1 (21), p. 38-44. (In Russ.).

5. Mamedov M. N. Petrologiya $i$ geohimiya pozdnemelovyh $i$ eocenovyh magmaticheskih formacij Malogo Kavkaza i Talysha [Petrology and geochemistry of the Late Cretaceous and Eocene magmatic formations of the Lesser Caucasus and Talysh]. Baku, Nafta-Press publ., 1999, 400 p. (İn Russ.).

6. Azizbekov Sh. A., Mamedov M.N. Ceolity subshchelochno bazal'toidnoj formacii Talysha [Zeolites of the Talysh subalkaline basaltoid formation]. Izv. AN ASSR. ser. Nauki o Zemle. - Izv. Academy of Sciences of the ASSR. ser. Earth sciences, 1974, no. 3, p. 83-95. (İn Russ.).

7. Belyankin D.S., Samoilova N.V., Petrov V.P. Anal'cim i lejcit v vulkanicheskom eocena Talysha [Analcime and leucite in the Talysh volcanic Eocene]. Trudy mineralogicheskogo muzeya [Proceedings of the Mineralogical Museum]. Moscow, Akademii nauk SSSR publ., 1951, vol. 3, pp. 3-9. (İn Russ.).

8. Amirov S. T., Mamedov M. N., Mamedov Kh. S. Ceolity Azerbajdzhana (Gornyj Talysh) [Zeolites of Azerbaijan (Mountain Talysh)]. Issled. V obl. neorg. i fizik. khimii [Research in the field of inorganic and physical chemistry]. Baku, Elm publ., 1977, pp. 190202. (İn Russ.).

9. Abdullaev R. N., Alizade H. A., Kheirov M. B. Bentonitoobrazovanie i ceolitovaya mineralizaciya v melovyh otlozheniyah Malogo Kavkaza (Kazahskij progib) [Bentonite formation and zeolite mineralization in the Cretaceous deposits of the Lesser Caucasus (Kazakh trough)]. Petrological and mineralogical features of rocks and technical stones. Moscow, Nauka, 1979, pp. 170-180. (İn Russ.).

10. Rasulova S. K. O nekotoryh zakonomernostyah ceolitovoj mineralizacii v pozdnemelovyh vulkanegenno-osadochnyh kompleksah Kazahskogo progiba (Malyj Kavkaz) [On some regularities of zeolite mineralization in the Late Cretaceous volcano-sedimentary complexes of the Kazakh trough (Lesser Caucasus)]. Vestnik Bakinskogo Universiteta, seriva estestvennykh nauk - Bulletin of the
Baku University, series of natural sciences, 2015, no. 2, pp. 92-99. (İn Russ.).

11. Rasulova S. K., Baba-zade V. M. Belousov P. E., Mamedov M. N., Imamverdiev N. A., Kerimov V. M., Vikentiev I. V. Usloviya obrazovaniya ceolitovyh mestorozhdenij Kazahskogo progiba Malogo Kavkaza [Conditions for the formation of zeolite deposits of the Kazakh trough of the Lesser Caucasus]. Vestnik RUDN. Seriya: Inzhenernye issledovaniya - Bulletin of RUDN. Series: Engineering Research, 2017, vol. 18, no. 4, p. 480-496. (İn Russ.).

12. Kuliev A. I., Gamzaev O. D. Tseolity Geologiya SSSR. T. 47. Poleznye iskopaemye [Zeolites Geology of the USSR. Vol. 47. Mineral resources]. Moscow, Nedra publ., 1976, 105 p. (İ Russ.).

13. Chelishchev N. F., Berenshtein B. G., Volodin V. F. Ceolity novyj tip mineral'nogo syr'ya [Zeolites a new type of mineral raw materials]. Moscow, Nedra publ., 1987, 176 p. (İn Russ.).

14. Azizbekov Sh. A., Bagirov A. E., Veliev M. M., Ismail-zade A. D., Nizheradze N. Sh., Emelyanova E. N., Mamedov M. N. Geologiya $i$ vulkanizm Talysha [Geology and volcanism of Talysh]. Baku, Elm publ., 1979, 246 p. (İn Russ.).

15. Kerimov V. M. Petrologiya i mineral'nyj paragenezis trahibazal't-trahiandezit-fonolitovoj formacii Talyshskoj zony. Diss. kand. geol.-min. nauk [Petrology and mineral paragenesis of the trachybasalt-trachyandesite-phonolite formation of the Talysh zone. dis ... cand. geol.-min. sciences]. Baku, 2007, 22 p. (İn Russ.).

16. Ismail-zade A. D., Mustafaev F. A. O ceolitah Talysha [On zeolites of Talysh]. Izv. AN Azerb. SSR. ser. geol.-geogr. nauk. Baku - Izv. AN Azerb. SSR. ser. geol.-geogr. sciences. Baku, 1964, no. 5, pp. 65-70. (İn Russ.).

17. Mamedov M. N., Babaeva G. D., Kerimov V. M. Klinopirokseny $\mathrm{v}$ processe formirovaniya subshchelochnoj olivin-bazal'tovoj magmy Talyshskoj zony Kavkaza [Clinopyroxenes during the formation of subalkaline olivine-basaltic magma of the Talysh zone of the Caucasus]. Ural'skii Geologicheskii Zhurnal - Ural Geological Journal, 2017, no. 5 (119), pp. 39-54. (İn Russ.).

18. Kerimov V. M. Geologicheskie usloviya formirovaniya trahibazal't-trahiandezibazal't-fonolitovoj formacii Talyshskoj zony (Azerbajdzhan) [Geological conditions for the formation of the trachybasalt-trachyandesite-basalt-phonolite formation of the Talysh zone (Azerbaijan)]. Ecoenergetika NTZh, 2016, no. 4, pp. 50-55. (In Russ.).

19. Kerimov V. M. Usloviya generacii subshchelochnyh i shchelochnyh bazal'toidnyh serij Talysha [Conditions for the generation of subalkaline and alkaline basaltoid series in Talysh]. Ural'skii Geologicheskii Zhurnal - Ural Geological Journal, 2020, no. 3 (135), pp. 35-43. (İn Russ.).

20. Mikhailov A. S. Mestorozhdeniya vysokokremnistyh ceolitov Zakavkaz'ya [Deposits of high-siliceous zeolites of Transcaucasia]. Sovetskaya geologiya -Soviet Geology, 1975, no. 9, pp. 70-78. (In Russ.).

21. Chkheidze R. G. Mestorozhdeniya vysokokremnistyh ceolitov Zakavkaz'ya i geologicheskie predposylki ih osvoeniya. Diss. dokt. geol.-min. nauk [Deposits of high-siliceous zeolites of the Transcaucasus and the geological prerequisites for their development. Abstract of Ph.D. diss. ... Cand. geol.-min. sciences]. Tbilisi, 1981, 25 p. (İn Russ.).
Керимов Вагиф Мирзамехти - к. г.-м. н., доцент, кафедра Геология нефти и газа, Азербайджанский государственный университет Нефти и Промышленности, Баку, Азербайджан; E-mail: vaqifkerimov1968@gmail.com; ORCID: https://orcid.org/0000-0001-8849-7696

Автор прочитал и одобрил окончательный вариант рукописи.
Vagif M. Karimov - PhD in Geol-Min., Associate Professor, Azerbaijan State Oil and Industry University, Baku, Azerbaijan; E-mail: vaqifkerimov1968@gmail.com; ORCID: https://orcid.org/0000-0001-8849-7696 Author have read and approved the final manuscript. 